\title{
ウォータージェットを用いた底泥下砂質土の 揚砂メカニズムに関する研究 MECHANISM OF THE SAND-UPWELLING WITH A UNDERGROUND WATER JET
}

\author{
大谷英夫 1 後藤仁志 ${ }^{2} \cdot$ 熟見崇 $^{3} \cdot$ 伊藤一教 1
}

Hideo OHTANI, Hitoshi GOTOH, Takashi SUMI and Kazunori ITO

1正会員 工修 大成建設(株)技術センター土木技術研究所海洋水理研究室

( ₹245-0825 神奈川県横浜市戸塚区名瀬町344-1)

2 正会員 工博 京都大学助教授 工学研究科都市環境工学専攻( $7606-8501$ 京都府京都市左京区吉田本町)

3学生会員 京都大学大学院工学研究科都市環境工学専攻( ( $606-8501$ 京都府京都市左京区吉田本町)

The new sand capping method had been proposed in later years. The method wells up buried sands by a water jet to cover the contaminated sludge on the bottom surface. Hydraulic model tests were carried out in order to find the parameters which control the up-welling sand flux, as the first step in establishing the estimation method of the upwelling-sand volume by the new sand capping method. As a result of model tests, the followings were revealed. The excavated hole was filled with the liquefactive sand which showed complex stream with vortices. The jet discharge rate and the grain size had larger influence on the up-welling sand flux than the jet velocity and the descending speed of jet pipe. To represent the phenomena from the hydrodynamic viewpoint, the numerical simulation with the Lagrangian model of solid-liquid two phase flow was carried out for the initial stage of the upwelling. The results were in good agreement with the phenomenon observed by the model tests.

Key Words : sand capping works, sand up-welling, water jet, solid-liquid two phase flow model, model test

\section{1 はじめに}

湖沼や内湾などの閉鎖性水域では，アオコや赤潮の発 生，水質の貧酸素化に悩まされている．水域環境改善対 策として污濁底泥の浚渫や覆砂が実施されているが, 浚 渫土の処分場の確保, 覆砂のための良質な砂の入手等に ついて問題を抱えている。このような問題に対処するた め, 第一著者は, 砂の持込を必要としない覆砂工法「底 泥置換覆砂工法」の開発に取り組んできた1).

底泥置換覆砂工法は, 底泥下の砂層からジェット水流 により揚砂させ底泥を覆砂するものである. 工法の原理 を図一 1 に示す。まず，湖底をジェット水流で掘削しな がらジェット管を砂質土層まで沈め，さらに，流量を増 しジェット管を降下させていく.ジェットにより掘削さ れた砂が注入された水とともに混相流状態でガイド管を 通って上方に排出される.ガイド管の上端口から流出す る砂は污濁底泥上に沈降しながら下向きの流れを連行す るので, 濁りや浮泥の巻き上げがほとんど発生しない. 底泥置換覆砂工法において，揚砂量を施工前に精度よ
く予測することは覆砂機の設計や施工計画にとって非常 に重要な課題である. ジェット水流により発生する揚砂 量は, ジェットの流量, 流速, 地盤のせん断強度, 粒径

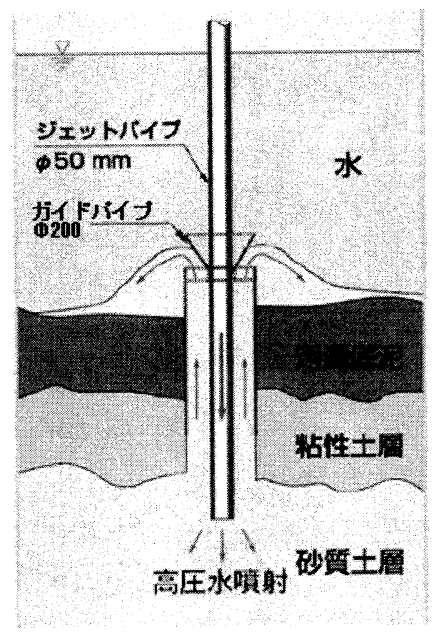

図-1 底泥置換覆砂工法の原理 
表-1 実験条件

\begin{tabular}{|c|c|c|c|c|c|c|c|c|c|c|c|c|}
\hline No. & $\begin{array}{l}\text { ジェツト管 } \\
\text { 径 } D(\mathrm{~cm})\end{array}$ & $\begin{array}{l}\text { 半割2 } \\
\text { 管1 }\end{array}$ & $\begin{array}{l}\text { 粒径 } d \\
(\mathrm{~mm})\end{array}$ & $\begin{array}{l}\text { 流量 } Q \\
(\mathrm{~m} 3 / \mathrm{min})\end{array}$ & $\begin{array}{l}V_{j} \\
(\mathrm{~m} / \mathrm{min})\end{array}$ & $\begin{array}{l}V_{o} \\
(\mathrm{~m} / \mathrm{s})\end{array}$ & $\begin{array}{l}\text { 揚砂量 } V_{s} \\
\left(\mathrm{~cm}^{3}\right)\end{array}$ & $\begin{array}{l}\text { 揚砂 } \\
\text { 時間 } \\
\text { (s) }\end{array}$ & $\begin{array}{l}\text { 揚砂中 } \\
\text { 水量 }\left(\mathrm{m}^{3}\right)\end{array}$ & $\begin{array}{l}\text { 揚砂中掘削 } \\
\text { 深さ }(\mathrm{m})\end{array}$ & $\begin{array}{l}\text { 含砂量 } \\
C_{s}(\%)\end{array}$ & $\begin{array}{l}\text { 揚砂フラックス } \\
q_{s}(\mathrm{~cm} 3 / \mathrm{min})\end{array}$ \\
\hline 1 & 1.67 & 2 & 0.2 & 0.0160 & 0.53 & 2.43 & 517 & \begin{tabular}{|l|}
15 \\
\end{tabular} & 0.0040 & 0.13 & 12.9 & 2068 \\
\hline 2 & 1.67 & 2 & 0.2 & 0.0160 & 0.71 & 2.43 & 2388 & 62 & 0.0165 & 0.73 & 14.4 & 2311 \\
\hline 3 & 1.67 & 2 & 0.2 & 0.0160 & 1.33 & 2.43 & 1397 & 33 & 0.0088 & 0.73 & 15.9 & 2541 \\
\hline 4 & 1.67 & 2 & 0.2 & 0.0160 & 0.21 & 2.43 & 4375 & 213 & 0.0568 & 0.73 & 7.7 & 1232 \\
\hline 5 & 1.67 & 2 & 0.2 & 0.0160 & 0.52 & 2.43 & 3000 & 85 & 0.0227 & 0.73 & 13.2 & 2118 \\
\hline 6 & 1.67 & 2 & 0.2 & 0.0096 & 0.44 & 1.46 & 1561 & 100 & 0.0160 & 0.73 & 9.8 & 936 \\
\hline 7 & 1.67 & 2 & 0.2 & 0.0241 & 0.43 & 3.67 & 5304 & 96 & 0.0386 & 0.68 & 13.8 & 3315 \\
\hline 8 & 1.67 & 2 & 0.2 & 0.0321 & 0.60 & 4.88 & 6394 & 63 & 0.0337 & 0.63 & 19.0 & 6090 \\
\hline 9 & 1.67 & 1 & 0.2 & 0.0096 & 0.33 & 0.73 & 2258 & 132 & 0.0211 & 0.73 & 10.7 & 1027 \\
\hline 10 & 1.67 & 1 & 0.2 & 0.0160 & 0.52 & 1.22 & 2932 & 85 & 0.0227 & 0.73 & 12.9 & 2069 \\
\hline 11 & 1.67 & 1 & 0.2 & 0.0321 & 0.50 & 2.44 & 7099 & 76 & 0.0407 & 0.63 & 17.5 & 5604 \\
\hline 12 & 1.67 & 2 & 0.6 & 0.0160 & 0.50 & 2.43 & 392 & 33 & 0.0088 & 0.27 & 4.5 & 712 \\
\hline 13 & 1.67 & 2 & 0.6 & 0.0241 & 0.49 & 3.67 & 1628 & 43 & 0.0173 & 0.35 & 9.4 & 2272 \\
\hline 14 & 1.67 & 2 & 0.6 & 0.0321 & 0.49 & 4.88 & 1321 & 20 & 0.0107 & 0.16 & 12.3 & 3962 \\
\hline 15 & 1.67 & 2 & 0.6 & 0.0160 & 1.33 & 2.43 & 1322 & 29 & 0.0077 & 0.64 & 17.1 & 2734 \\
\hline 16 & 5.00 & 2 & 0.6 & 0.2500 & 0.79 & 4.24 & 17864 & 32 & 0.1333 & 0.42 & 13.4 & 33495 \\
\hline 17 & 5.00 & 2 & 0.6 & 0.3750 & 0.79 & 6.37 & 20645 & 19 & 0.1188 & 0.25 & 17.4 & 65194 \\
\hline 18 & 5.00 & 2 & 0.6 & 0.1500 & 0.82 & 2.55 & 11209 & 47 & 0.1175 & 0.64 & 9.5 & 14309 \\
\hline 19 & 5.00 & 2 & 0.6 & 0.5000 & 0.79 & 8.49 & 25060 & 19 & 0.1583 & 0.25 & 15.8 & 79138 \\
\hline 20 & $1.67 i$ & 2 & 0.07 & 0.0160 & 1.30 & 2.43 & 1334 & 37 & 0.0099 & 0.80 & 13.5 & 2164 \\
\hline 21 & 1.67 & 2 & 0.07 & 0.0160 & 0.53 & 2.43 & 3160 & 84 & 0.0224 & 0.74 & 14.1 & 2257 \\
\hline 22 & 1.67 & 2 & 0.07 & 0.0321 & 0.49 & 4.88 & 6275 & 70 & 0.0375 & 0.57 & 16.8 & 5379 \\
\hline
\end{tabular}

などの影響を受けると考えられる，施工の対象とする地 盤は，事前のボーリング調査により $\mathrm{N}$ 值，粒径，粒度構 成などが明らかにされるが，それは施工場所に特有のも ので全国一律ではない，さらに，地盤も硬さや粒度など 質が異なる複数の砂層で構成されているため, 揚砂量を 正確に予測することは非常に難しい問題である. 現状で は，施工前の試験覆砂により覆砂量を求めているが，物 理的なメカニズムが明らかになれば合理的な覆砂量予測 への道が拓かれるであろう。

本研究では，揚砂量予測の第一歩として水理模型実験 により揚砂機構を調べ, 同時に現象の数値シミュレー ションを試みた. 水理模型実験では, 粒径, ジェット流 量が与える揚砂量への影響を明らかにした．数値シミュ レーションは固液二相流型のMPS法 ${ }^{2)}$ 用い，揚砂量予 測手法への可能性を確認した。

\section{2. 水理模型実験}

\section{（1）実験方法}

実験は，図-2に示す幅 $62.5 \mathrm{~cm}$ の水槽で行った。ジェッ トによる揚砂中の砂層内状況を可視化するため, ガイド 管は半割管を使用し，ジェット管は水槽のガラス面に沿 わしながら降下させた。一定流量で複数のジェット流速 条件を実現するため, ジェット管は半割り管と円管の2 種類を使用した，各管の寸法は，現地で使用したもの ${ }^{1)}$ を参考にした，砂層厚は $80 \mathrm{~cm}$ とた，砂層表面には， 揚砂した砂を完全に捕捉するため, 透水性が高く砂粒子 を通さないジオテキスタイルを敷いた．実験条件を表-1 に示す． $V_{j}$ はジェット管の降下速度， $V_{o}$ はジェット流速 である，砂層に用いたケイ砂の粒径 $d$ は，中央粒径が $0.6 \mathrm{~mm}, 0.2 \mathrm{~mm}, 0.07 \mathrm{~mm}$ の種類である. 模型は実機相

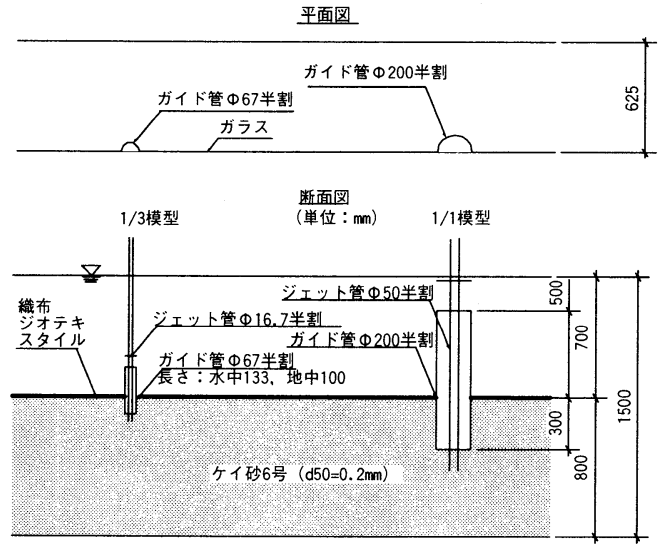

図-2＼cjkstart水理実験のセットアップ

当の模型（縮尺1:1model）および模型（縮尺1:3model） の2つ用意した。実機相当の1:1model（表-1：No.16, $q_{s}=$ $33495 \mathrm{~cm}^{3} / \mathrm{min}$ ) と $1: 3$ model （表 $-1 ：$ No1， $q_{s}=$ $2068 \mathrm{~cm}^{3} / \mathrm{min}$ ) で揚砂量の相似性を確認した結果, 揚砂 フラックス $q_{s}$ (単位時間当たりの揚砂量と定義) がほほ 縮尺比の 2.5 乗の值となり, 相似性は満足されたと言え る。なお，砂層厚が十分にとれないため，主に $1 / 3$ 模型 で実験を行った．また，後述するジェットによる掘削孔 の幅は水槽の幅より小さく，水槽の幅による揚砂量への 影響はないことを確認した。

流量 $Q$ は，実機相当で， $0.3 \mathrm{~m}^{3} / \mathrm{min}, 0.5 \mathrm{~m}^{3} / \mathrm{min}, 0.75$ $\mathrm{m}^{3} / \mathrm{min}, 1.0 \mathrm{~m}^{3} / \mathrm{min}$, ジェット管の降下速度 $V_{j}$ は, 実機相 当で, $0.35 \mathrm{~m} / \mathrm{min}, 0.87 \mathrm{~m} / \mathrm{min}, 1.73 \mathrm{~m} / \mathrm{min}, 2.3 \mathrm{~m} / \mathrm{min}$ とし た． $V_{j}$ は，管を吊るしたウインチの速度で調節した，実 験は, ジェット水流の先端が水槽底面に達するまで行っ た.この間, 水底に揚砂された砂の体積は, 覆砂形状が 円錐台となることから，放射状に3測線で高さ，広がり 


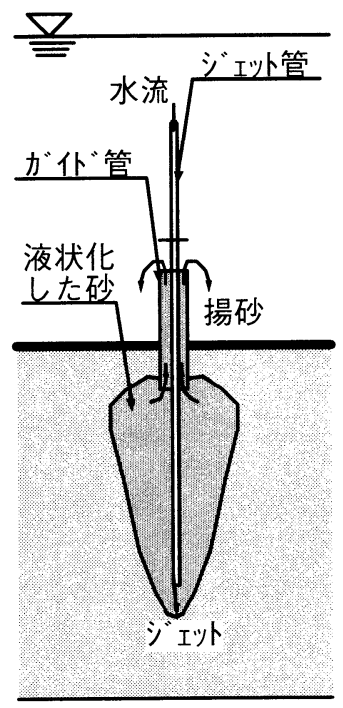

(a) 掘削中

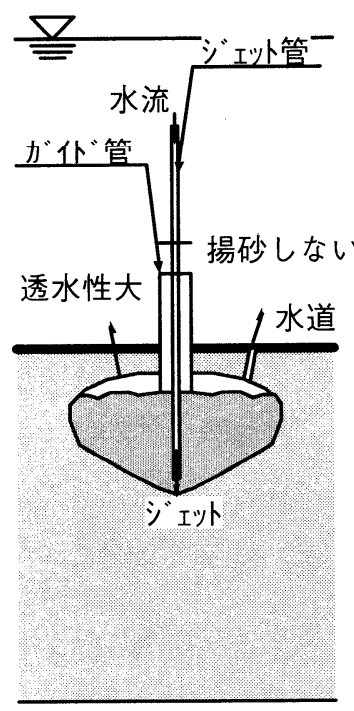

（b）水道ができた場合
図-3 覆砂中の砂層内状況

を計測し，それらの平均から円錐台体積の公式により計 算した。砂粒径が $d=0.07 \mathrm{~mm}$ のケースの揚砂量は, 覆砂 形状が円錐台形状にならなかったため, 実験後ジオテキ スタイル上の砂を掃除機で集め, 乾燥重量と乾燥密度を 計測して求めた. コーン貫入抵抗を確認した結果各ケー ス $1900 \mathrm{k} \mathrm{N} / \mathrm{m}^{2}$ から2000kN/m²でほぼ同一の值であった。

\section{（2）実験結果および考察}

\section{a）揚砂中の砂層内状況}

砂層内では，ジェットにより砂が掘削され液状化し， 砂は水に連行されガイド管から外部に定常的に排出され るという2つのプロセスにより揚砂が行われていた。 ジェット管を降下させながら掘削を続けると, ジェット 管に沿う楔形で液状化した砂で満たされた掘削孔が形成 された（図-3a）。掘削孔の中の流れは，揚砂を支える 大循環に局所的な渦のセル構造か加わった複雑な流れの 様相を示した，掘削孔は，流量が大きいケースで拡大す る傾向を示した。これは流量の増大に伴い揚砂フラック スが増大することを示唆するものである．また，砂粒径 が最も小さい $d=0.07 \mathrm{~mm}$ のケースでは, 掘削孔が切り 立った壁を持つ細長い形状を呈した．写真-1はジェット 管の降下を停止し，ジェットを作用させ続けた状況であ る. 砂はガイド管より排出され，底面に円錐台形状で堆 積している，砂層内では，掘削孔の周囲の砂が崩れ側方 へと拡大しハート型の掘削孔形状となった。このハート 型の掘削孔は液状化した砂層と，その上の水だけの層で 構成された. 掘削孔が側方へ大きく拡大しても揚砂は続 くケースがほとんどであるが，突如として揚砂が停止し たケースがあったこの現象は粒径 $d=0.6 \mathrm{~mm}$ の砂のケー スで顕著で,掘削孔から水底面への水道の形成あるいは

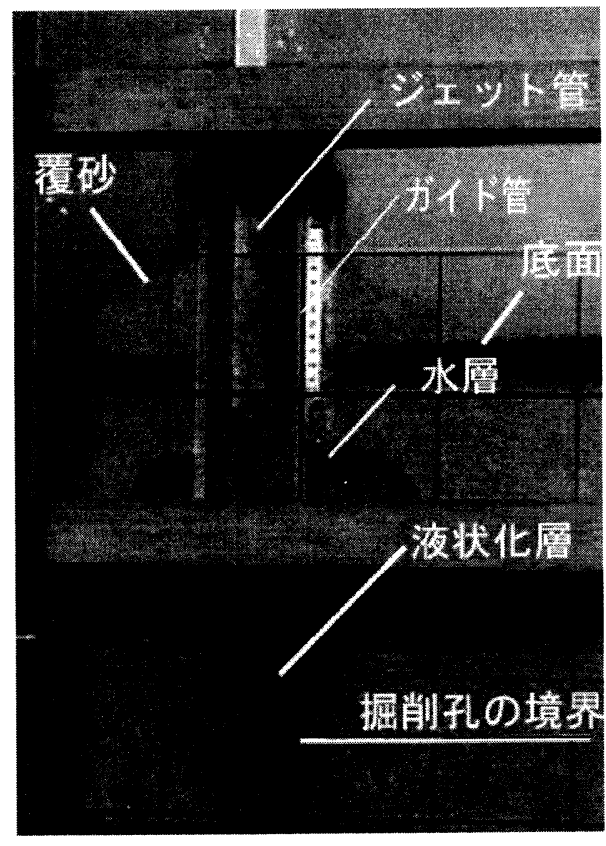

写真-1 実験状況

掘削孔の内圧による水底への浸透流流量の増大によって， 掘削孔内の水圧が低下し，ガイド管内の上昇流速が低下 して揚砂が不可能になっていたことを染料水による観察 から確認した（図-3b）。粒径 $d=0.6 \mathrm{~mm}$ のケースでこの 現象か顕著に見られたのは, 透水係数が大きいこと, 砂 粒子の質量が大きく細砂に比べ揚砂に大きな流速が必要 であることが理由であることが考えられる．また，掘削 孔が大きくなりすぎて水底面に達した場合もガイド管上 部からの揚砂が停止した。 ガイド管より排出された砂の 広がり方は, 粒径が $d=0.2 \mathrm{~mm}, d=0.6 \mathrm{~mm}$ のケースはほぼ 水中安息角の斜面を持つ円錐台形状で堆積し, 粒径が $d=0.07 \mathrm{~mm}$ のケースでは円錐台形状にはならず，ほぼ平 坦に遠方まで広がった。 なお, 揚砂終了後, 掘削孔は周 囲の砂が崩れ，埋め戻された。

\section{b）揚砂量に影響する因子}

ガイド管から排出される砂の状況を目視した結果では, 揚砂フラックス（単位時間の揚砂量）が増大したのは次 の 2 つの場合であった. (1)流量を大きくした場合，(2) ジェット管を降下させた場合である. (1)については，流 量の増加とともに流速が増大し, 流れの運動量に起因す る掘削力が強まり, さらに揚砂に寄与する上昇流の流速 も増大するためと考えられる. (2)はジェット管を一定の 位置に停止させている場合と比べて，降下させた時の方 が揚砂フラックスの濃度が高いという意味である. 砂面 に作用する流速にジェット管の降下速度が加わること, ジェット管の出口と砂層面が常に接近し大きい流速が砂 面に作用する状況にあることの理由で掘削の効果が増大 したと考えられる。

以上の仮説を検証するため，揚砂量に影響する因子と して, ジェット流量 $Q$ （図-4）, ジェット降下速度 $V_{j}$ 


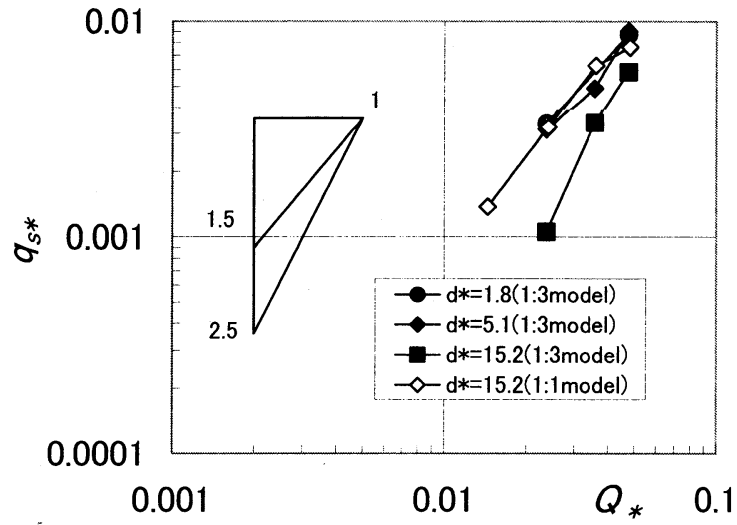

図-4＼cjkstart揚砂フラックスと流量の関係

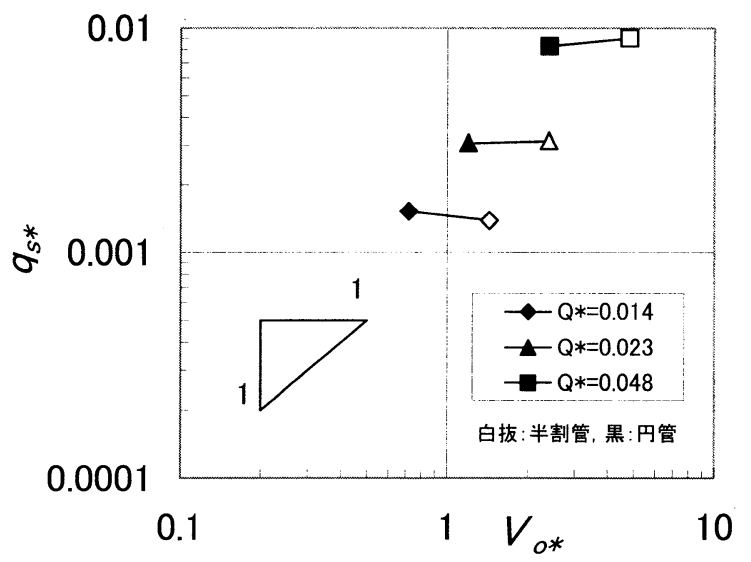

図-6＼cjkstart揚砂フラックスとジェット流速の関係

（図-5），ジェット流速 $V_{o}$ （図-6），砂の粒径d（図7）に着目し，揚砂量に与える基本的な特性を調べた. 砂層のせん断強度も大きな影響を与えるはずであるが, セットアップ上大変な労力を使うことになるため本研究 では取り扱わない. なお，各物理量は砂の密度 $\sigma$ と水 の密度 $\rho$ の比を $\mathrm{s}=(\sigma / \rho-1)=1.65$ とし, 次のように無次 元化した.

$$
\begin{aligned}
& q_{s^{*}}=q_{s} / \sqrt{g L^{5}} \\
& Q_{*}=Q / \sqrt{g L^{5}} \\
& V_{j^{*}}=V_{j} / \sqrt{g L} \\
& V_{0^{*}}=V_{0} / \sqrt{g L} \\
& d_{*}=(d \sqrt{\operatorname{sgd}} / v)^{2 / 3}
\end{aligned}
$$

ただし， $g$ : 重力加速度， $\nu$ : 動粘性倸数，L:ガイド 管の半円周である.

揚砂フラックス $q_{s^{*}}$ と流量 $Q_{*}$ の関係（図-4）は, ジェットの降下速度 $V_{j^{*}}$ (図-5)，ジェット流速 $V_{o^{*}}$ （図-6），粒径 $d_{*}$ （図-7）に比べて傾きが大きく流量の

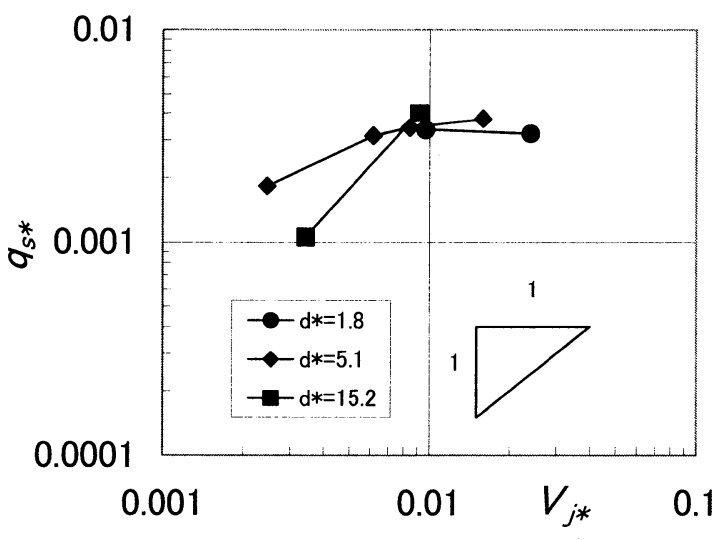

図-5 揚砂フラックスとジェット降下速度の関係

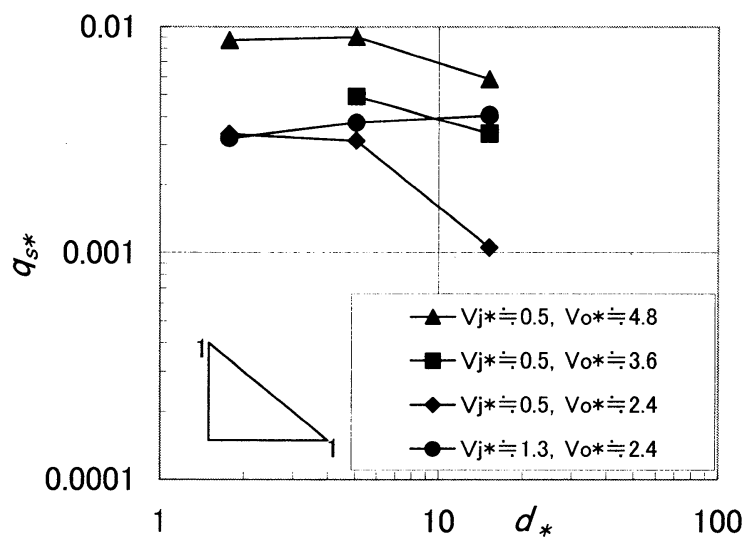

図-7 揚砂フラックスと粒径の関係

1.5乗から 2.5 乗に比例した. これにより，他の因子に比 べ揚砂フラックスに与える影響が大きいことがわかる. 流量か増大すると, ジェット流速か増大し砂層への掘削 効果が大きくなり，同時に上昇流速増大による揚砂効果 も高まり，揚砂フラックスが増大したと考えられる。

揚砂フラックス $q_{s^{*}}$ とジェット管降下速度 $V_{j^{*}}$ の関係 （図-5）は， $V_{j^{*}}$ が大きいと $q_{s^{*}}$ も大きくなる正の相関を示 した。ただし，前にも述べたが写真-1のように汸が0で も揚砂フラックスは発生する．前述の(2)に関する仮説が 定量的に示された.

揚砂フラックス $q_{s^{*}}$ とジェット流速 $V_{o^{*}}$ の関係は， $V_{o^{*}}$ が 大きいと $q_{s^{*}}$ は大きくなる傾向を示した（図-6）。ジェッ 卜管のノズルを絞るなどの処置を行い流速 $V_{0}$ 大きくし， 砂層の掘削効果の増大を試みる場合を想定し, 同一流量 の条件トのデータを佰線で結んで流量の影響を排除した。 この結果, 本研究の実験条件程度の砂層の硬さでは ジェット流速の影響は小さく流量が同一であれば $q_{s}$ は変 わらない. 言い替えれば， $q_{s^{*}}$ ことってジェット管口元近 傍の局所的な流速の影響は小さく, 空間的に広い領域の， また，掘削された砂を水底まで揚げるに寄与する流速， すなわち流量の影響が卓越すると言える。

図-7には，同一ジェット流速，同一ジェット管降下速 度の条件における，揚砂フラックス $q_{s^{*}}$ と砂粒径 $d *$ の関係 
を示した. 大局的に粒径が大きいほど揚砂フラックスが 小さくなった. 粒径が大きくなれば沈降速度が大きくな り揚砂抵抗が増大寸ることが原因であると判断できる. 特に粒径が大きくなるほど負の傾きが増し, 揚砂フラッ クス低減効果が大きい.

\section{3. 揚砂過程の数值シミュレーション}

ここでは, 前章で示した底泥置換覆砂工法の物理プロ セスを，固液混相流モデルによって再現する，泥層表面 の複雑な形状を追跡するため, 界面の複雑な変形を良好 に追跡できるLagrange型のモデルを適用する.

\section{（1）基礎式}

後藤ら ${ }^{2)}$ の二流体型の固液二相流モデルによる粒子レ ベルの運動方程式は以下のようになる。

$$
\begin{aligned}
& \rho_{l} \frac{\mathrm{D} \mathbf{u}_{l}}{\mathrm{D} t}=-\nabla p_{l}+\mu_{l} \nabla^{2} \mathbf{u}_{l}+\mathbf{f}_{l s p}+\rho_{l} \mathbf{g} \\
& \rho_{s} \frac{\mathrm{D} \mathbf{u}_{s}}{\mathrm{D} t}=-\nabla p_{s}+\mu_{s} \nabla^{2} \mathbf{u}_{s}-\mathbf{f}_{l s p}+\rho_{s} \mathbf{g}+\mathbf{f}_{c o l p}
\end{aligned}
$$

ここに, $\mathbf{u}_{\mathrm{m}}$ : 流速べクトル, $p_{m}$ : 圧力, $\rho_{m}$ : 各相の密 度, $\mathbf{f}_{k p p}$ : 固相・液相間相互作用力ベクトル, $\mathbf{g}$ : 重力加 速度べクトル, $\mu_{m}$ : 粘性係数, $\mathbf{f}_{c o l p}$ : 固相粒子間衝突力 ベクトル，添字 $m=l, s$ は液相および固相を表している. なお，グリッドを用いた離散化では，固・液両相の物 理量が全てのグリッドで定義されるが，粒子法では，各 粒子は固相粒子・液相粒子の何れかである. 故に粒子法 では, 各相間の相互作用が粒径の数倍（重み関数の影響 半径程度）のスケールで取り扱われることとなる。

粒子 $i$ の圧力項および粘性項は,

$$
\begin{gathered}
-\frac{1}{\rho}\langle\nabla p\rangle_{i}=-\frac{1}{\rho} \frac{D_{0}}{n_{0}} \sum_{j \neq i}\left\{\frac{p_{j}-p_{i}}{\left|\mathbf{r}_{i j}\right|^{2}} \mathbf{r}_{i j} \cdot w\left(\mid \mathbf{r}_{i j}\right)\right\} \\
v\left\langle\nabla^{2} \mathbf{u}\right\rangle_{i}=\frac{2 v D_{0}}{n_{0} \lambda} \sum_{j \neq i}\left(\mathbf{u}_{j}-\mathbf{u}_{i}\right) w\left(\left|\mathbf{r}_{i j}\right|\right) \\
\lambda=\sum_{j \neq i} w\left(\left|\mathbf{r}_{i j}\right|\right)\left|\mathbf{r}_{i j}\right|^{2} / \sum_{j \neq i} w\left(\left|\mathbf{r}_{i j}\right|\right) \\
\mathbf{r}_{i j}=\mathbf{r}_{j}-\mathbf{r}_{i} \\
w(r)= \begin{cases}\frac{r_{e}}{r}-1 & \text { for } r \leq r_{e} \\
0 & \text { for } r>r_{e}\end{cases}
\end{gathered}
$$

のように近傍に存在する粒子との相互作用としてモデル 化される ${ }^{3)}\left(D_{0}\right.$ : 次元数 $; r_{i}$ : 粒子 $i$ の位置べクトル ; $w(r)$ : 重み関数 ${ }^{4)}$ (相互作用の影響範囲 $) ; r$ : 距離 ; $r_{e}$ : 影響半径）。そこで，固相粒子の運動に関して，圧 力項および粘性項を固相粒子間（添字 $s s ）$ と固相・液相 粒子間（添字 $l s ） に$ 分けて，粒子の回転や粒子近傍での
局所的な非定常性などの副次的な要素を無視すれば，固 相粒子の運動方程式は,

$$
\begin{aligned}
\rho_{s} \frac{\mathrm{D} \mathbf{u}_{s}}{\mathrm{D} t}= & \left(-\nabla p+\mu \nabla^{2} \mathbf{u}\right)_{l s}+\rho_{s} \mathbf{g} \\
& +\mathbf{f}_{c o l p}+\left(-\nabla p+\mu \nabla^{2} \mathbf{u}\right)_{s s}
\end{aligned}
$$

と書ける.この式で,

$$
\left(-\nabla p+\mu \nabla^{2} \mathbf{u}\right)_{l s}=\text { 流体力 }
$$

であるから，

$$
\mathbf{f}_{c o l p}+\left(-\nabla p+\mu \nabla^{2} \mathbf{u}\right)_{s s}=\text { 固相粒子間相互作用 }
$$

と意味付けることができる5)。

\section{(2) 固相粒子間相互作用モデル}

固相粒子間の相互作用モデルは, MPS法の固相粒子 （計算点）と同一径，同一質量の仮想的円盤を導入し, 接触する円盤間にスプリング-ダッシュポットを置いて 相互作用をモデル化する個別要素法型の取り扱いとする. 固相粒子間の相互作用は,

$$
\mathbf{f}_{\text {colp }}=\left[\begin{array}{c}
\sum_{j}\left\{-f_{n} \cos \alpha_{i j}+f_{s} \sin \alpha_{i j}\right\}_{j} \\
\sum_{j}\left\{-f_{n} \sin \alpha_{i j}+f_{s} \cos \alpha_{i j}\right\}_{j}
\end{array}\right]
$$

と書ける. $f_{n}, f_{s}$ : 固相粒子 $i, j$ 間の法線(添字 $\left.\mathrm{n}\right)$ および接 線(添字 $s$ )方向の作用力, $\alpha_{i j}$ : 固相粒子 $i, j$ の接触角であ る.

土砂の粘着性の表現のため, 法線方向に引つ張り抵抗 を想定して, 粒子間距離の10\%を越える変位が累積する までは結合が切断されないように設定している.

\section{（3）計算領域}

計算領域を図-8に示す．計算負荷の問題から，実際の 水槽と同一のサイズでの計算の実行はできないので，ノ ズルの周囲の地盤を対象に, ジェット噴出初期の砂の巻 き上げ・排出過程に的老絞った計算を実施した。粒子総 数6270（その内, 水粒子 1500 , 砂粒子 2400 , 表層泥（粘 着性材料）粒子180）である. 固相間の粘着性は, 表層 泥についてのみ考慮し, 砂層の粒子については標準型の 二流体モデルで処理した。ジェット管の降下速度は

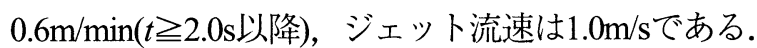

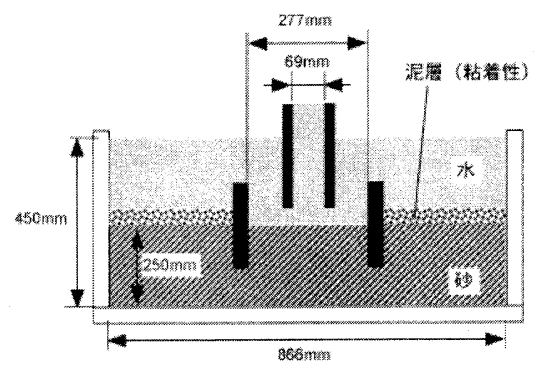

図-8 計算領域 

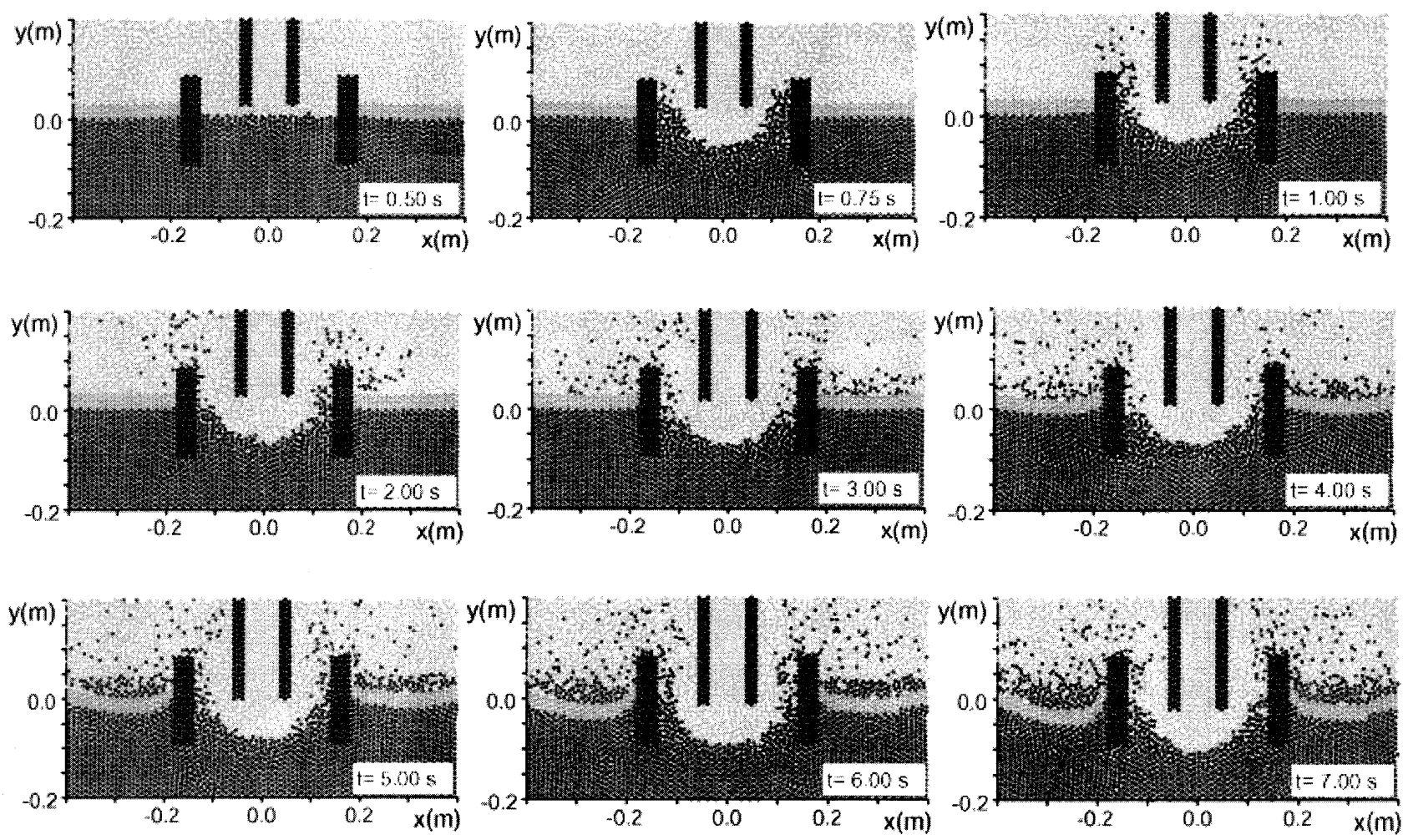

図-9＼cjkstart覆砂の初期過程のシミュレーション

\section{(4)計算結果}

ジェット噴射直後から 7.0 秒間の状態をシミュレー ションした結果を図-9に示す。ジェットに掘削された砂 がガイド管内の上昇流に連行されて表層に排出されるプ ロセスが模擬されている. ジェット開始とともにジェッ 卜管直下の砂はジェット管の両脇へ移動し，ガイド管と ジェット管の隙間を通って水底に揚がり，時間の経過と ともに表層泥層を覆砂が進行している. ジェット管の下 降とともにジェット管の真下の砂が掘削されるが, ジェット管の口元と掘削砂面の距離は時間に寄らずほぼ 一定であること，ジェット管下方の掘削面が円弧状であ ることなど，実験結果とよく一致している，なお，ガイ 管外縁と表層泥層が粘着接合された条件であるので, 時間の経過とともに表層泥層上に砂が堆積すると, 泥層 がたわむように変形した。

\section{5. おわりに}

底泥置換覆砂工法における揚砂機構の明確化と揚砂量 の正確な予測を目的として水理実験と数值計算を実施し た. 水理実験では，ジェットによって液状化した掘削孔 内を，砂が水に連行されガイド管より排出される状況を 可視化するとともに, 覆砂量はジェット流量, 砂粒径に 大きく影響され，それらに比べジェット流速やジェット
管の降下速度の影響は小さいことが明らかとなった．今 後は, 現地の実測とあわせて覆砂量の予測式を構築して いく予定である。 また，複雑な地層を対象とした揚砂量 予測の将来実現を目指して流体力学的な見地からの理解 を進めるためMPS法を用いた解析を試みた。計算はまだ 初期段階のみであるが，水理実験で見られた現象の本質 的な部分が再現され，今後の研究の第一ステップが刻ま れたと考方られる。

\section{参考文献}

1) 大谷英夫 $\cdot$ 上野成三 -小林篻男 - 岡田和夫 - 織田幸伸: 底 泥置換覆砂工法の開発と施工, 海洋開発論文集, 第19巻, pp.421-426, 2003.

2) 後藤仁志・Jørgen Fredsøe：Lagrange型固液二相流モデルによ る海洋投棄微細土砂の拡散過程の数值解析, 海岸工学論文集, 第46巻, p. $986-990,1999$.

3) 越塚誠一: 数值流体力学, インテリジェントエンジニアリン グシリーズ, 培風館, p223, 1997.

4) Koshizuka, S. and Oka, Y.: Moving-particle semi-implicit method for fragmentation of incompressible fluid, Nuclear Science and Engineering, Vol. 123, pp.421-434, 1996.

5) 後藤仁志 - 林 稔 · 安藤 怜. 酒井哲郎：固液混相流解析の ためのDEM-MPS法の構築, 水工学論文集, 第47巻, pp.547$552,2003$.

(2003.9.30受付) 